\title{
Examining Attitudes of Physical Education Teacher Education Program Students Toward the Teaching Profession
}

\author{
Gunay Yildizer ${ }^{1}$, Caner Ozboke ${ }^{1}$, Ramazan Tascioglu ${ }^{1}$ and Ilker Yilmaz ${ }^{1}$
}

Affiliations: 'Anadolu University, Faculty of Sport Sciences, Department of Physical Education and Sport Teaching, Eskişehir, Turkey

\begin{abstract}
Correspondence: Gunay Yildizer, Anadolu University, Faculty of Sport Sciences, 2 Eylül Campus, Department of Physical Education and Sport Teaching, Tepebaşı/Eskişehir. E-mail: gunayyildizer@gmail.com

ABSTRACT The purpose of this study was to investigate attitudes of pre-service teachers toward the teaching profession with respect to their gender, grade level, whether participants regularly participate in physical activities, and whether pre-service students have a teacher-parent in their family. Research was conducted on 469 pre-service physical education teachers $($ Mage $=21.35$, SDage $=2.49), 188$ female $($ Mage $=20.89$, SDage $=$ $2.30)$ and 281 male (Mage=21.66, SDage $=2.57)$ students from five different universities in Turkey. In this study the "Attitude Scale for the Profession of Physical Education Teaching" was used. It has two factors: "concern for profession" (CP) and "affection for profession" (AP). Independent sample t-test results indicated that there were no significant differences with respect to gender or having a teacher-parent in both factors and total attitude points $(\mathrm{p}>0.05)$. Pre-service physical education teachers who participate in physical activity had significantly higher points in AP and the total scale in comparison to those who do not participate in physical activity $(\mathrm{p}<0.05)$. ANOVA results indicated that based on grade level there were significant differences in $\mathrm{CP}$ and total attitude $(\mathrm{p}<0.05)$. Students' concern about employment may be associated with differences in attitude scores between grade levels. The positive effect of physical activity participation and their professional teaching education on stress resilience might also be an important factor for increasing positive attitudes toward the teaching profession.
\end{abstract}

KEY WORDS Attitudes toward Profession, Physical Education and Sport, Pre-service Teacher.

@MJSSMontenegro

ATTITUDES TOWARD THE TEACHING PROFESSION

http://mjssm.me/?sekcija=article\&artid=139

\section{Introduction}

Personal or community development and change in one's desired course with respect to culture, knowledge, abilities and attitudes are only achievable through education (Demirhan, 2006). Teachers, students, and education programs are the essential components of the educational process (Sönmez, 2014). Teachers might be seen as the core of these components as they are responsible for guiding students to achieve the desired outcome according to the education program. Demirtaş, Cömert and Özer (2011) indicated that the teaching profession has decisive and directive roles beyond the other factors such as physical environment and other components in the educational process.

As stated in the literature, the effectiveness of the teaching profession is dependent on three crucial factors (i) profession choices of pre-service teachers, (ii) quality of teacher training, and (iii) teachers' personal beliefs towards the teaching profession (Şişman, 1999). The belief system is diversified from other factors that affect the quality of education, as it is deeply resistant to change (Kagan, 1992). However, studies have elucidated how belief system of teachers have been formed (Tsangaridou, 2006). Literature has theoretically demonstrated that the belief system of teachers is formed in three consecutive periods; (i) during their experiences in school, (ii) from life experiences, (iii) during their professional teacher education program in university (Pajares, 1992). 
Kullinna, Brusseau, Ferry, and Cothran (2010) emphasized the belief system of teachers as "When beliefs function to make a decision or call for action, they become important and a group of beliefs clustered around a situation or object becomes an attitude that is prone to action". Attitudes can be defined as individual's mental, emotional, and behavioural forms of expected behaviour to an environmental object, social issue or experience. In line with these definitions, Kirel (2011) explained attitude as "personal feelings, ideas and adopting particular behaviours to other people, situations or objects". Teachers attitudes can lead their decisions and may affect teacher's behaviours in this way (Pajares, 1992). Considering the ways attitude towards teaching take form and influence teaching behaviors, it is important to understand pre-service teachers' attitudes. In this perspective, how pre-service teachers are restructuring belief system and attitudes in order to adopt appropriate instructional practices are key. Early educational experiences during childhood (Rovegno, 2003), early field experiences as a teacher (Woods, Goc Karp, \& Escamilla, 2000) are important factors to consider.

Studies that examine pre-service teachers' attitudes toward the teaching profession have analysed different variables. Terzi and Tezci (2007) specified that pre-service teachers have a positive attitude towards their profession. In some studies, female pre-service teachers have demonstrated higher attitude scores than male pre-service teachers have (Pehlivan, 2010; Sağlam, 2008; Terzi \& Tezci, 2007) yet there were no significant differences between genders in other studies (Özder, Konedrall, \& Zeki, 2010). The years spent in a bachelor program as an indicator of educational experience was also considered while examining differences in pre-service physical education teachers' attitudes. Research demonstrated that program messages are incorporated into pre-service teachers' belief system about teaching physical education related to content, teaching effectiveness, and planning (Matanin \& Collier, 2003). Therefore, years spent in a teacher education program becomes a critical issue in terms of attitudes. To illustrate, Ünlü (2013) reported that attitude scores of Turkish pre-service physical education students linearly decreased from the first year to the last year of their education.

In contrast, previous studies with pre-service teachers suggest that culturally based assumptions regarding sport and physical education were important factors as pre-service teachers progressed through their professional development (Rovegno, 2003). The physical education teacher education program is in the context of sport. Considering that most physical educators and pre-service physical education teachers share athletic backgrounds, it is important to investigate effectiveness this common sport culture on attitudes toward teaching. However, there is limited literature on this variable. Similar to physical education culture, having a teacher-parent in the family is another cultural background that might be shared by pre-service teachers (Pehlivan, 2008). However, there is an insufficient body of literature investigating the effects of this variable on attitudes in the physical education context.

To date, comprehending factors associated with positive attitudes toward teaching has been vital in order to improve the quality of teaching. The purpose of this study was to examine the pre-service physical education teachers' self-reported attitudes toward the teaching profession by gender (men and women), grade levels (1st, 2nd, 3rd and 4th), regular physical activity participation (yes/no), and whether they have a teacherparent in their family or not (yes/no). Therefore, based on previous literature we hypothesized that (1) there is no significant difference between attitude points of male and female pre-service physical education teachers, (2) there are significant differences among pre-service teachers from different grades, (3) there are significant differences between pre-service teachers who regularly participate in physical activities and ones who do not, and finally (4) there are significant differences between pre-service teachers who have a teacher-parent in their family and who do not.

\section{Methods}

Participants

The participants of this study were 478 pre-service physical education teachers from five different universities in Turkey. Nine of them was excluded from the study because of inaccurate or incomplete filling of the instrument. Therefore, the study was completed with 469 participants; 281 males (Mage=21.66, SDage=2.57) and 188 females (Mage $=20.89$, SDage $=2.30$ ) pre-service physical education teachers completed the study: 180 participants were in the 1st grade, 134 participants were in the 2 nd grade, 105 participants were in the $3 \mathrm{rd}$ grade, and 50 participants were in the 4 th grade. Demographic information about the participants is shown in Table 1.

\section{Design of the Study}

A descriptive survey model was implemented in this study. Data were collected by the same researchers in all data collection centres. Gender, grade level, physical activity participation status (yes/no) and having a teacherparent in the family (yes/no) were the independent variables and coded as categorical variable. In contrast, attitude scores in both AP, CP, and total scale were dependent variables. Physical activity participation was coded as a categorical variable, not as the physical activity level. This is a limitation of this study.

\section{Instruments}

Demographic measures are obtained by self-reported age, grade level, physical activity participation status, and having a teacher-parent in the family. 


\begin{tabular}{lcc}
\hline TABLE 1 Demographic information of participants & Frequency & $\%$ \\
\hline Gender & 188 & 40.1 \\
\hline Female & 281 & 59.9 \\
Male & 469 & 100 \\
\hline Total & 180 & 38.4 \\
\hline Grade Level & 134 & 28.6 \\
\hline 1st & 105 & 22.4 \\
2nd & 50 & 10.7 \\
3rd & 469 & 100 \\
\hline th & 324 & 69.1 \\
\hline Total & 145 & 30.9 \\
\hline Physical Activity Status & 469 & 100 \\
\hline Yes & 151 & 32.2 \\
No & 318 & 67.8 \\
\hline Total & 469 & 100 \\
\hline Teacher in the Family & & \\
\hline Yes & & \\
No & & \\
\hline Total & & \\
\hline
\end{tabular}

Attitudes toward teaching profession were assessed using 23-item 5-point Likert-type scale developed and validated by Ünlü (2011). This scale consists of two subscales. Affection for the profession (AP) is assessed with 13 positive items and Concern for Profession (CP) is assessed with 10 negative items which indicate that lower scores in this subscale emphasize higher concern levels. In Ünlü's (2011) study both exploratory and confirmatory factor analyses conducted to check the validity of the instrument, and it was validated with satisfactory values. Moreover, internal consistency values were assessed with Cronbach's alpha values and revealed 0.90 for $\mathrm{AP}$, for $0.86 \mathrm{CP}$ and 0.88 total scale, respectively, in the original research. In our study, Cronbach alpha values were found 0.76 for AP, 0.85 for CP and 0.86 for total scale. Cronbach Alpha values, which were greater than 0.70 , show that scale has high-level internal consistency and that it distinguishes item in high and medium levels (Tabachnick \& Fidell, 2013).

\section{Data Collection Procedures}

To conduct the study, ethical approval was obtained by the Anadolu University Ethics Committee. Secondly, researchers contacted the heads of Physical Education and Sport Teaching departments from five different universities, and they all chose to support this study. Two researchers visited these universities, explained the purpose of the study, and collected data from pre-service physical education who wanted to participate.

\section{Data Analysis}

Data analysis was conducted on 469 surveys. This number is sufficient according to Nunnally's (1978) recommendations on required sample size for survey studies. It highlighted that required sample size is 10 for each item in the survey. Therefore, the sample size in this study is sufficient.

Before conducting analysis, variables were examined to meet assumptions of the parametric tests. Statistics of variables showed that skewness and kurtosis values were between the range of -0.60 to $-0.53,-0.77$ to 0.22 and -0.71 to -0.26 for total attitude score, AP, and CP respectively. These values met the \pm 1.50 criterion (Tabachnick \& Fidell, 2013). Independent sample t-tests were separately conducted to understand differences between the independent variables "gender", "physical activity participation" and "having a teacher-parent in the family". In addition to t-tests, one-way ANOVA was conducted to understand the differences between grade levels in terms of their attitude scores. IBM SPSS 22.0 (Chicago, IL) was used to conduct analyses. The significance level was determined to be 0.05 .

\section{Results}

Independent samples t-test results indicated that there were no significant differences between male and female pre-service physical education teachers in the AP subscale [Male $(\mathrm{M}=4.18, \mathrm{SD}=0.50)$, Female $(\mathrm{M}=$ $4.22, \mathrm{SD}=0.48), \mathrm{t}(467)=-0.72, \mathrm{p}=0.467$ ], the $\mathrm{CP}$ subscale $[$ Male $(\mathrm{M}=3.85, \mathrm{SD}=0.81)$, Female $(\mathrm{M}=3.92, \mathrm{SD}=$ $0.78), \mathrm{t}(467)=-0.88, \mathrm{p}=0.378$ ], and the total attitude point [Male $(\mathrm{M}=4.04, \mathrm{SD}=0.54)$, Female $(\mathrm{M}=4.08, \mathrm{SD}=$ $0.53), t(467)=-0.94, p=0.344]$. Although there were no significant differences between genders, descriptive statistics indicated that female pre-service physical education teachers had greater scores in the AP and CP subscales in comparison to their male counterparts. Similarly, female participants had greater total attitude points in comparison to male participants (Table 2). 
TABLE 2 Independent t-test results with respect to gender variable

\begin{tabular}{lccccc} 
Gender & $\begin{array}{c}\text { Affection for Profession } \\
\text { Mean } \pm \text { SD }\end{array}$ & p & Concern for Profession & \multicolumn{2}{c}{ Total Attitude Score } \\
\hline Male & $4.18 \pm 0.50$ & 0.467 & $3.85 \pm 0.81$ & Mean \pm SD & p \\
Female & $4.22 \pm 0.48$ & & $3.92 \pm 0.78$ & 0.378 & $4.04 \pm 0.54$ \\
\hline
\end{tabular}

Legend: $p>0.05$

One-way ANOVA results indicated that the grade level variable was a significant factor for attitudes toward the profession among pre-service physical education teachers. In other words, ANOVA results indicated that there were significant differences in total attitude points $[\mathrm{F}(3,465)=5.20, \mathrm{p}=0.002]$ and $\mathrm{CP}$ subscale $[\mathrm{F}$ $(3,465)=7.09, \mathrm{p}=0.000]$ but not in $\mathrm{AP}[\mathrm{F}(3,465)=1.70, \mathrm{p}=0.165]$ among pre-service PE teachers from different grade levels. Tukey post-hoc test was employed to understand differences among groups and results are shown in Figure 1. First-year students $(M=4.17, \mathrm{SD}=0.49)$ had significantly higher total attitude points in comparison to third-year $[(\mathrm{M}=3.96, \mathrm{SD}=0.51), \mathrm{p}=0.009]$ and fourth-year students $[(\mathrm{M}=3.91, \mathrm{SD}=0.61)$, $\mathrm{p}=0.011]$. Secondly, first-year students $(\mathrm{M}=4.08, \mathrm{SD}=0.68)$ had significantly higher scores in the $\mathrm{CP}$ subscale in comparison to second-year $[(\mathrm{M}=3.78, \mathrm{SD}=0.81), \mathrm{p}=0.002]$, third-year $[(\mathrm{M}=3.73, \mathrm{SD}=0.81), \mathrm{p}=0.006]$ and fourth-year students $[(\mathrm{M}=3.66, \mathrm{SD}=0.93), \mathrm{p}=0.005]$. Finally, there were no significant differences between first-year $(\mathrm{M}=4.24, \mathrm{SD}=0.48)$, second-year $(\mathrm{M}=4.22, \mathrm{SD}=0.50)$, third-year $(\mathrm{M}=4.14, \mathrm{SD}=0.47)$, and fourthyear students $(\mathrm{M}=4.10, \mathrm{SD}=0.49)$ for the AP subscale.

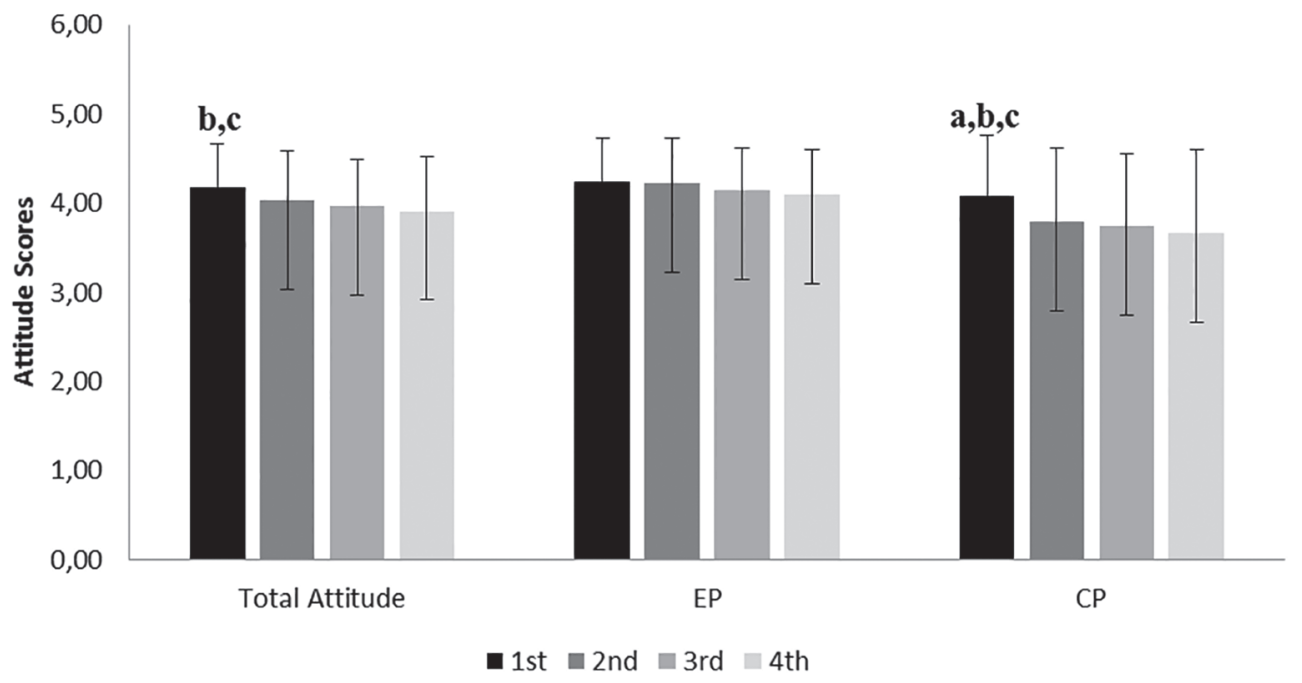

FIGURE 1 Attitude scores according to year of study (a: Difference between 1st and 2nd; b: Difference between 1st and $3 \mathrm{rd}$; c: Difference between 1st and 4th)

A total of 151 participants reported that they have a teacher parent in the family, and 318 reported they do not have teacher-parent in the family. Independent samples t-test results indicated that there were no significant differences between these two groups in AP $[\mathrm{t}(467)=-1.13, \mathrm{p}=0.257]$ and $\mathrm{CP}[\mathrm{t}(467)=-0.31, \mathrm{p}=0.752]$ subscales and total attitude score $[\mathrm{t}(467)=-0.79, \mathrm{p}=0.430]$. Descriptive statistics and $\mathrm{t}$-test results are shown in Table 3.

TABLE 3 Independent t-test results with respect to teacher in family variable

\begin{tabular}{ccccccc}
\multirow{2}{*}{ Teacher in Family } & \multicolumn{2}{c}{ Affection for Profession } & \multicolumn{2}{c}{ Concern for Profession } & \multicolumn{2}{c}{ Total Attitude Score } \\
& Mean \pm SD & p & Mean \pm SD & p & Mean \pm SD & p \\
\hline Yes & $4.16 \pm 0.50$ & 0.257 & $3.86 \pm 0.83$ & \multirow{2}{*}{0.752} & $4.03 \pm 0.57$ & 0.430 \\
No & $4.21 \pm 0.48$ & & $3.88 \pm 0.77$ & & $4.07 \pm 0.51$ & \\
\hline
\end{tabular}

Legend: $p>0.05$

As previously emphasized, physical activity culture is a key factor for attitude variables in physical education context; 324 of the participants reported that they regularly participate in physical activities and 145 of them reported that they do not participate regularly in any physical activity. Independent samples t-test results showed that participants who regularly participate in physical activities had significantly higher scores in comparison to those who do not participate in physical activity AP [Active ( $\mathrm{M}=4.25, \mathrm{SD}=0.49)$, Non-Active $(\mathrm{M}=4.09, \mathrm{SD}=0.46), \mathrm{t}(467)=3.30, \mathrm{p}=0.001$ ] and total attitude scores [Active $(\mathrm{M}=4.09, \mathrm{SD}=0.53)$, NonActive $(\mathrm{M}=3.98, \mathrm{SD}=0.54), \mathrm{t}(467)=2.05, \mathrm{p}=0.041$ ], but not in $\mathrm{CP}$ [Active $(\mathrm{M}=3.89, \mathrm{SD}=0.78)$, Non-Active $(\mathrm{M}=3.84, \mathrm{SD}=0.83), \mathrm{t}(467)=0.54, \mathrm{p}=0.583]($ Table 4$)$. 


\begin{tabular}{|c|c|c|c|c|c|c|}
\hline \multirow{2}{*}{ Physical Activity } & \multicolumn{2}{|c|}{ Affection for Profession } & \multicolumn{2}{|c|}{ Concern for Profession } & \multicolumn{2}{|c|}{ Total Attitude Score } \\
\hline & Mean \pm SD & $\mathbf{p}$ & Mean \pm SD & $\mathbf{p}$ & Mean \pm SD & $\mathbf{p}$ \\
\hline Yes & $4.25 \pm 0.49$ & \multirow{2}{*}{$0.001^{*}$} & $3.89 \pm 0.78$ & \multirow{2}{*}{0.583} & $4.09 \pm 0.53$ & \multirow{2}{*}{$0.041^{*}$} \\
\hline No & $4.09 \pm 0.46$ & & $3.84 \pm 0.83$ & & $3.98 \pm 0.54$ & \\
\hline
\end{tabular}

Legend: ${ }^{*}-p<0.05$

\section{Discussion}

In this study, pre-service PE teachers' attitudes towards teaching were examined with respect to gender, grade level, physical activity participation, and having a teacher-parent in the family. The first null hypothesis of the study was not rejected as there are no significant differences between male and female pre-service PE teachers. In all subscales of the questionnaire, males and females have reported similar attitude scores towards teaching. Descriptive statistics indicated that female pre-service PE teachers have higher affection, total attitude score and lower concerns for profession comparing to male counterparts. These results are in line with previous literature (Bedel, 2008; Pehlivan, 2010). Doğan \& Çoban (2009) explained that teaching profession was perceived as female profession and females are more willing to become a teacher in Turkish culture. On the contrary; Güneyli \& Arslan (2009) has demonstrated that gender is detrimental variable for attitudes toward teaching. A possible explanation to insignificant attitude scores between genders may be attributed to the specific domain. Most of the physical education teachers have professional athletic background, and Pajares (1992) indicated that life experiences are one of the crucial factors for the shaping belief system of teachers. Sandıkçı and Öncü (2013) reported that despite the similar results of attitude scores among teachers from various departments, $\mathrm{PE}$ teachers were the only group for which there is no main gender effect on teaching efficacy.

Our results indicated that the total attitude and effectiveness for teaching profession scores linearly decreased, whereas concern for the profession was linearly increase with respect to students' grades, thus indicating that first-year students have the highest scores in total attitude and affection subscales and the lowest concern level for the profession. The significant differences were observed between first- and third-, first- and fourthyear students for total attitude scores and first- and second-, first- and third-, first- and fourth-year students for concern for profession scores. Pehlivan (2010) also reported that positive attitudes toward teaching are decreasing in the middle and latest levels of the educational process among pre-service PE teachers. A possible explanation could be related to post-graduation stress, which indicates high concern for finding an appropriate job related to individuals' education (Doğan \& Çoban, 2009). Moreover, it has been reported that negative beliefs about the teaching profession may lead to negative attitudes toward it among pre-service teachers (Inman \& Marlow, 2004).

The results of our study indicated that having a teacher-parent in a family does not make a difference in attitude scores on any subscale in comparison to those who do not have teacher-parent in their family. As Rovegno (2003), suggested that teachers transfer early educational experiences during childhood to the educational process in professional life; teacher parents might have an effect on these experiences. To illustrate, Archer et al. (2012) reported that the family habitat and social capital of the family is effective on children's science aspiration and potential future participation among a 10-14 years old English population. Insufficient information on how parents in the teaching profession shape attitudes toward the academic life of children does not allow the comprehension of how teachers transfer their family background to attitudes related to teaching.

Participants who regularly participate in physical activity reported that they have significantly higher affection in the profession and total attitude score in comparison to those who do not. It was expected that the regular physical activity participation would increase the positive attitudes toward physical education teaching among pre-service PE teachers. In line with our results, Pehlivan (2010) reported the regular participation in sport has positive effect on attitudes toward the teaching profession among pre-service teachers. A possible explanation may be attributed to occupational stress. It is a well-established fact that physical activity reduces stress levels and improves mental health among adults and college-aged individuals (Wu, Tao, Zhang, Zhang, \& Tao, 2015). Gerber, Jonsdottir, Lindwall, and Ahlborg (2014) suggested that physical activity participation is associated with resilience to occupational stress. Thus, decreased level of stress related to occupation may be effective on positive attitudes towards teaching profession among pre-service PE teachers. More specifically, literature has demonstrated that physical activity participation is one of the major strategies for coping with stress for teachers (Austin, Shah, \& Muncer, 2005).

Our study has some methodological limitations. The physical activity level was obtained by self-report as a categorical variable, and this may have led to social-desirability bias. Moreover, future studies are needed to determine how family background and physical activity level rather than participation status affect the attitudes toward teaching among pre-service PE teachers. Finally, the sample sizes with respect to grade levels were distributed unequally because of the central teacher assignment exam, which takes place in the last year 
of teacher education. Therefore, fourth-year students are generally out of faculties to prepare for this exam. Future studies in the Turkish context should consider these factors to be a limitation.

In conclusion, although female pre-service teachers have more positive attitude scores toward the teaching profession than their male counterparts do, there were no significant differences between genders. Moreover, there were no differences between pre-service teachers with respect to the teacher in a family variable. Therefore, the presence of teacher-parents does not affect pre-service physical education teachers in terms of different aspects of attitude. In contrast, physical activity participation is essential for increasing positive attitudes toward teaching through decreasing stress levels. However, it is also important to clarify the possible relationship between physical activity level and attitudes towards teaching, rather than physical activity participation preferences. Finally, pre-service PE teachers are likely to increase their concerns about teaching with the upgrading grade level. This is most probably attributed to stress caused by the central teacher assignment exam. Therefore, it is important to consider stress as a variable in future studies focusing on attitudes towards teaching among pre-service teachers in the Turkish context.

\section{REF ERENCES}

Archer, L., DeWitt, J., Osborne, J., Dillon, J., Willis, B., \& Wong, B. (2012). Science aspirations, capital and family habitus how families shape children's engagement and identification with science. American Educational Research Journal, 49(5), 881-908.

Austin, V., Shah, S., \& Muncer, S. (2005). Teacher stress and coping strategies used to reduce stress. Occupational Therapy International, 12(2), 63-80.

Bedel, E. F. (2008). Interactions among attitudes toward teaching and personality constructs in early childhood preservice teachers. Journal of Theory and Practice in Education, 4(1), 31-48.

Demirhan, G. (2006). Spor eğitiminin temelleri. Ankara: Bağırgan Yayınevi.

Demirtaş, H., Cömert, M., \& Özer, N. (2011). Öğretmen adaylarının öz yeterlik inançları ve öğretmenlik mesleğine ilişkin tutumları. Eğitim ve Bilim, 36(159), 96-111.

Doğan, T., \& Çoban, A. E. (2009). Eğitim fakültesi öğrencilerinin mesleğine yönelik tutumları ile kaygı düzeyleri arasındaki ilişkinin incelenmesi. Eğitim ve Bilim, 34(153), 157-168.

Gerber, M., Jonsdottir, I. H., Lindwall, M., \& Ahlborg, G. (2014). Physical activity in employees with differing occupational stress and mental health profiles: A latent profile analysis. Psychology of Sport and Exercise, 15(6), 649-658.

Güneyli, A., \& Aslan, C. (2009). Evaluation of Turkish prospective teachers' attitudes towards teaching profession (Near East University case). Procedia-Social and Behavioral Sciences, 1(1), 313-319.

Inman, D., \& Marlow, L. (2004). Teacher retention: Why do beginning teachers remain in the profession? Journal of Education, 124(4), 605-614.

Kagan, D. M. (1992). Implication of research on teacher belief. Educational Psychologist, 27(1), 65-90.

Kırel, Ç. (2011). Sosyal psikoloji. (S. Ünlü, Ed.), Tutum ve tutum değişimi. Eskişehir: Anadolu Üniversitesi Açıöğretim Fakültesi Yayını.

Kullinna, H. P., Brusseau, T., Ferry, M., \& Cothran, D. (2010). Preservice teachers' belief systems toward curricular outcomes for physical education. Research Quarterly for Exercise and Sport, 81(2), 189-198.

Matanin, M., \& Collier, C. (2003). Longitudinal analysis of preservice teachers' beliefs about teaching physical education. Journal of Teaching in Physical Education, 22(2), 153-168.

Nunnally, J. C. (1978). Psychometric theory. New York: McGraw-Hill.

Özder, H., Konedralı, G., \& Zeki, C.P. (2010). Öğretmen adaylarının öğretmenlik mesleğine yönelik tutumlarının çeşitli değişkenler açısından incelenmesi. Educational Administration: Theory and Pratice, 26(2), 253-275.

Pajares, M. F. (1992). Teachers' beliefs and educational research: Cleaning up a messy construct. Review of Educational Research, 62(3), 307-332.

Pehlivan, B. (2008). Sınıf öğretmeni adaylarının sosyo-kültürel özellikleri ve öğretmenlik mesleğine yönelik tutumları üzerine bir çalışma. Mersin University Journal of the Faculty of Education, 4(2), 151-168.

Pehlivan, Z. (2010). Beden eğitimi öğretmen adaylarının fiziksel benlik algıları ve öğretmenlik mesleğine yönelik tutumlarının analizi. Eğitim ve Bilim, 35(156), 126-141.

Rovegno, I. (2003). Teachers' knowledge construction. (In S. Silverman, C. Ennis, Ed.) Student learning in physical education: Applying research to enhance instruction, pp. 295-310. Champaign, IL: Human Kinetics.

Sağlam, A. Ç. (2008). Müzik öğretmenliği bölümü öğrencilerinin öğretmenlik mesleğine yönelik tutumları. Yüzüncü Yıl Üniversitesi Ĕ̆itim Fakültesi Dergisi, 5(1), 59-69.

Sandıkçı, M., \& Öncü, E. (2013). Beden eğitimi ile diğer alanlardaki öğretmen adaylarının öğretmenlik mesleğine ilişkin yeterlik algıları ve tutumlarının belirlenmesi ve karşılaştırılması. Pamukkale Journal of Sport Sciences, 1(4), 135-151.

Sönmez, V. (2014). Eğitimin tarihsel temelleri. In Eğitim Bilimlerine Giriş (11th ed.). Ankara: Anı Yayıncılık.

Şişman, M. (1999). Öğretmenlik mesleğine giriş. Ankara: Pegem A Yayıncllık.

Tabachnick B. G., \& Fidell L. S. (2013). Using multivariate statistics (6th Edition). Boston: Allyn and Bacon.

Terzi, A. R., \& Tezci, E. (2007). Necatibey Eğitim Fakültesi öğrencilerinin öğretmenlik mesleğine ilişkin tutumları. Kuram ve Uygulamada Eğitim Yönetimi, 52, 593-614. 
Tsangaridou, N. (2006). Trainee primary teachers' beliefs and practices about physical education during student teaching. Physical Education and Sport Pedagogy, 13(2), 131-152.

Ünlü, H. (2013). Do prospective physical education teachers really want to be physical education teachers? Croatian Journal of Education, 15(4), 211-230.

Ünlü, H. (2011). Beden eğitimi öğretmenliği mesleğine yönelik tutum ölçeği (BEÖYTÖ) geliştirilmesi. Kuram ve Uygulamada Eğitim Bilimleri, 11(4), 2005-2020.

Woods, M., Goc Karp, G., \& Escamilla, E. (2000). Preservice teachers learning about students and the teaching-learning process. Journal of Teaching in Physical Education, 20, 15-39.

Wu, X., Tao, S., Zhang, Y., Zhang, S., \& Tao, F. (2015). Low physical activity and high screen time can increase the risks of mental health problems and poor sleep quality among Chinese college students. PloS one, 10(3), e0119607. 